\title{
EDITORIAL
}

\section{DE RICHMOND A ARICA: EN MEMORIA DE MARVIN JEROME ALLISON}

\section{FROM RICHMOND TO ARICA: IN MEMORY OF MARVIN JEROME ALLISON}

\author{
Bernardo Arriaza ${ }^{1}$, Vivien G. Standen ${ }^{2}$, Calogero M. Santoro ${ }^{1}$ y Jorge Hidalgo ${ }^{3}$
}

Compartimos con los lectores de Chungara Revista de Antrpología Chilena la triste noticia del fallecimiento del Dr. Marvin J. Allison, ex académico de la Universidad de Tarapacá y profesor emérito en la Universidad de Virginia Commonwealth, Richmond, Virginia, Estados Unidos. Marvin fue uno de los grandes paleopatólogos y pioneros de la bioarqueología mundial, aunque poco reconocido en los ambitos académicos del "primer" mundo. Nació el 6 de enero 1921 y su partida se produjo el 23 junio de 2015. Marvin siempre decía: "viviré muchos años, mi familia es muy longeva", y ciertamente estaba en lo correcto, al fallecer a la respetable edad de 94 años.

Marvin era un estudioso y erudito de la patología y paleopatología. Fue profesor de microbiología en el Medical College of Virginia (MCV) y desde mediados de los años setenta, con sus colegas inseparables, Enrique Gerszten (MCV) y Juan Munizaga (Universidad de Chile), visitaban continuamente Latinoamérica especialmente Ilo (Perú) y Arica (Chile) para trabajar en establecer en este rincón del planeta la semilla de las investigaciones en paleopatología. Su primera visita a Arica se realizó en el verano de 1977, gracias a un convenio formal, en el invierno de 1976, entre Marvin Allison, Juan Munizaga y Jorge Hidalgo, permitió la utilización de fondos de National Geographic Society para realizar excavaciones sistemáticas en el cementerio municipal de San Miguel de Azapa, que se expandía vertiginosamente por esos años poniendo en riesgo el patrimonio arqueológico subyacente bajo las tumbas actuales. El trabajo de campo fue realizado por Calogero Santoro y sirvió de base para su memoria de título en la Universidad del Norte de Antofagasta. En el verano del año siguiente, 1978,
We share the sad news with the readers of Chungara Revista de Antropología Chilena of the death of Dr. Marvin J. Allison, a former Faculty at Universidad de Tarapacá and professor emeritus at Virginia Commonwealth University in Richmond, Virginia in the United States. Marvin was one of the great paleopathologists and a pioneer of bioarchaeology though poorly recognized within academic circles in the developed world. He was born January 6, 1921, and died June 23, 2015. Marvin always said, "I will live many years, my family is long-lived", and he was certainly right for he died at the respectable age of 94.

Marvin was a scholar and erudite of pathology and paleopathology. He was a microbiology professor at the Medical College of Virginia (MCV). From the mid-1970s onwards, he and two of his inseparable colleagues, Enrique Gerszten (MCV) and Juan Munizaga (Universidad de Chile), visited Latin America, especially Ilo (Peru) and Arica (Chile), striving to establish the seeds for future research in paleopathology in this corner of the world. His first visit to Arica occurred in the summer of 1977, thanks to a formal agreement in the winter of 1976 between Marvin Allison, Juan Munizaga and Jorge Hidalgo, that permit the utilization of funds from the National Geographic Society to carry out systematic excavations in the municipal cemetery of San Miguel de Azapa, which at the time was expanding vigorously, putting the surrounding archaeological patrimony at risk. Field work was done by Calogero Santoro and served as the basis for his bachelor thesis at Universidad del Norte in Antofagasta. The summer of the following year, 1978, Marvin Allison spent another research period

\footnotetext{
Instituto de Alta Investigación, Universidad de Tarapacá, Arica, Chile. barriazaarica@gmail.com; calogero_santoro@yahoo.com Departamento de Antropología, Universidad de Tarapacá, Arica, Chile. vstanden@chungara.cl

Facultad de Filosofía y Humanidades, Universidad de Chile, Santiago, Chile. jorgehidalgolehuede@gmail.com
} 
Marvin Allison volvió a pasar otra temporada de investigación y el destino, mediante la central de empleo para estudiantes de la Universidad del Norte, lo llevó a conocer a Bernardo Arriaza, lo que despertó en este último el ímpetu por desarrollar una carrera de investigación en el ámbito de la bioantropología y la paleopatología.

Después de jubilarse en los Estados Unidos, Marvin vio la conveniencia de radicarse en Arica, Chile, para formar parte del Museo Arqueológico San Miguel de Azapa, del Instituto de Antropología de la Universidad de Tarapacá, desde 1981 hasta 1988. En dicha unidad trabajó mancomunadamente con Guillermo Focacci, Luis Briones, Liliana Ulloa, Percy Dauelsberg, Calogero Santoro y en numerosos trabajos de campo, incluyendo las excavaciones arqueológicas de rescate de cementerios prehispánicos, producto de la creciente urbanización de la ciudad de Arica y de la expansión de los campos agrícolas en los valles de Azapa y de Lluta.

En ese entonces las momias y fardos funerarios precolombinos no solo eran destruidos por procesos naturales como la humedad, insectos y hongos, sino también por la carencia de políticas de conservación sobre restos humanos momificados. En esa época la antropología física tendía al estudio de los restos óseos y no se investigaban los tejidos orgánicos blandos. Marvin trajo procedimientos novedosos para efectuar estudios de esa materialidad que permitió ampliar considerablemente el horizonte de nuestros conocimientos sobre las enfermedades precolombinas. Marvin veía a las momias como una fuente de información incalculable, realizando numerosas autopsias para conocer las causas de muerte de poblaciones precolombinas. Como resultado de estos estudios escribió más de 200 artículos en revistas especializadas y fue profesor guía de numerosas tesis de pre y posgrado, principalmente de estudiantes extranjeros.

En el área de la paleopatología Marvin fue uno de los pioneros en plantear que las enfermedades infecciosas como la tuberculosis existían en la América precolombina. Hallazgos que más tarde fueron corroborados por otros investigadores. También reportó que las neumonías afectaban significativamente a las antiguas poblaciones como a las actuales y contribuyó sustancialmente al estudio de las técnicas de momificación Chinchorro y a posicionarlas en la comunidad internacional como tema relevante en la arqueología Americana temprana. En el museo implementó un laboratorio de antropología física, donde junto a sus (in Chile) and fate, through the student employment office at Universidad del Norte, lead him to meet Bernardo Arriaza, which awakened in the latter an impulse to develop a research career in the field of bioanthropology and paleopathology.

After retiring in the United States, Marvin saw the convenience of settling in Arica, Chile, to form part of the Museo Arqueológico San Miguel de Azapa staff, in the Instituto de Antropología at Universidad de Tarapacá, from 1981 to 1988. There he worked in collaboration with Guillermo Focacci, Luis Briones, Liliana Ulloa, Percy Dauelsberg, Calogero Santoro and in numerous fieldwork expeditions, including the archaeological excavations to rescue pre-Hispanic cemeteries, due to the growing urbanization of the city of Arica and the expansion of agricultural fields in the Azapa and Lluta Valleys.

At the time, not only were pre-Columbian mummies and funerary bundles destroyed by natural processes such as humidity, insects, and mold, but also due to the lack of conservation policies on mummified human remains. Furthermore, physical anthropology at the time tended to study osseous remains and not soft tissue. Marvin brought new procedures to study the latter, allowing us to considerably expand our knowledge of pre-Columbian diseases. Marvin saw mummies as a source of incalculable information, performing numerous autopsies to learn the causes of death of pre-Columbian populations. As a result of these studies, he wrote more than 200 articles in specialized journals and served as an advisor for numerous undergraduate and graduate theses, mainly from foreign students.

In the area of paleopathology, Marvin was one of the pioneers in suggesting that infectious disease, like tuberculosis, existed in pre-Columbian America. His findings were later corroborated by other investigators. He also reported that pneumonia significantly affected ancient populations just like it does today. In addition, he contributed substantially to the study of mummification techniques of the Chinchorro people and to position them in the international community as a relevant topic in early American archaeology. In the museum, he set up a laboratory of physical anthropology, where together with his collaborators they performed autopsies of ancient mummies, sharing his results when he found unexpected phenomena, such as individuals that died due to injury by a projectile point or women who died 
colaboradores realizaban las autopsias, compartiendo sus resultados cuando encontraba fenómenos insospechados como individuos que fallecieron por efecto de una punta de proyectil o de mujeres en el proceso de parto. En la bioarqueología contribuyó tanto con estudios de casos como de poblaciones. Algunos de sus trabajos se encuentran publicados en la Revista Chungara. Además, junto a Enrique Gerszten publicaron por décadas el Paleopathology Club Newsletter (http:// www.pathology.vcu.edu/paleo/index.html), donde compartían con la comunidad casos de paleopatología. También formó parte del consejo y cuerpo de consultores de la Revista Chungara desde 1981 hasta 1988. Sus estudios y contactos internacionales contribuyeron a que el Museo Arqueológico de la Universidad de Tarapacá se proyectará como un centro de investigación e interés mundial para muchos científicos.

Marvin era una persona muy inquieta de espíritu y en algunos aspectos académicos se adelantó casi 20 años a su época. A fines de los años setenta como profesor invitado de la Universidad de Norte y luego en la década de 1980, como académico de la Universidad de Tarapacá, fue uno de los pioneros en trabajar arduamente en la elaboración de un programa de postgrado en Antropología. Siempre le decíamos que se había adelantado a su época, pero su entusiasmo y proactividad lo llevaron a continuar con este y otros proyectos académicos institucionales, a pesar que no coincidían con los planes de desarrollo de la Universidad. El proyecto de una escuela de postgrado que él promovía, finalmente no prosperó por falta de profesores locales con grado de doctor, pero sirvió de estímulo para generar las condiciones mínimas al interior de la unidad de antropología, para que 20 años más tarde, en 2002, se lograra iniciar con éxito, junto con la Universidad Católica del Norte, un programa de Magíster en Antropología. Esta apuesta de postgrado escaló en 2006 a un programa de Doctorado, acreditado desde 2010. Esto gracias a recursos estatales, vía proyectos MECESUP, Fundación Andes y el Centro de Investigaciones del Hombre en el Desierto, que entre otros aportes trajo de vuelta a Chile, desde USA, a Bernardo Arriaza convertido en un prestigioso especialista en las líneas de investigación planteadas por Marvin.

En 1987 la Universidad de Tarapacá por decreto Exento No 538/87 nombró a Marvin Allison, Luis Álvarez, Percy Daueslberg, Luis Briones, Iván Muñoz y Alejandro Tapia, como comisión especial, cuyo objetivo era estudiar los Planes y Programas de in childbirth. In bioarchaeology, he contributed with case studies as well as with population analyses. Some of his work is published in Revista Chungara. In addition, together with Enrique Gerszten, they published the Paleopathology Club Newsletter (http://www.pathology.vcu.edu/paleo/index.html) for decades, where they shared paleopathology cases with the community. He was also a member of the editorial board of Revista Chungara from 1981 until 1988. His international studies and contacts contributed in launching the Museo Arqueológico from Universidad de Tarapacá as a research center of global interest for many scientists.

Marvin had a restless spirit and in some academic aspects was 20 years ahead of his time. During of the decade 1970s as a guest professor at Universidad del Norte, and then in the 1980s as a faculty member of Universidad de Tarapacá, he was one of the pioneers in working arduously in the creation of an anthropology postgraduate program. We always told him he was ahead of his time, but his enthusiasm and proactiveness lead him to continue with his academic vision and other institutional projects in spite of them not coinciding with the university's academic development plans. The project for an anthropology postgraduate program that he promoted, finally did not prosper due to the lack of local professors with a doctorate degree, but served as a stimulus to generate minimal conditions within the anthropology unit so that 20 years later, in 2002 together with Universidad Católica del Norte, a Masters Program in Anthropology could finally be successfully initiated. This postgraduate program was expanded in 2006, to include a doctorate program that have been accredited since 2010. This was possible thanks to government resources, via MECESUP projects, Fundación Andes, and the Centro de Investigaciones del Hombre en el Desierto, which among other contributions brought Bernardo Arriaza back to Chile from the USA, who has become a prestigious specialist in the lines of research proposed by Marvin.

In 1987 Universidad de Tarapacá, by exempt decree $N^{\circ}$ 538/87, named Marvin Allison, Luis Álvarez, Percy Daueslberg, Luis Briones, Iván Muñoz and Alejandro Tapia as members of a special commission, to examine the plans and programs of study for the creation of an undergraduate program in archaeology 
Estudio para la Creación de la Carrera de Arqueología en la Universidad de Tarapacá. Carrera de pregrado que tras este momento inicial y muchos esfuerzos colectivos posteriores, finalmente se concretó el año 2006, gracias a un aporte de MECESUP.

También su legado continúa en el Museo Arqueológico de Azapa donde actualmente funciona el laboratorio de Antropología Física que él comenzó. Se debe destacar que él contribuyó significativamente a la creación de los equipos de investigadores que han continuado en esas tareas. En este sentido fue un maestro cuya presencia aún se siente en el Departamento de Antropología por medio de los investigadores como Bernardo Arriaza y Vivien Standen, quienes se sintieron impulsados a obtener sus doctorados en esas especialidades de la bioantropología. Fue, por otra parte, un reconocido conferencista. Se interesó además por traer al país a especialistas que fueron los primeros que hicieron reconstrucciones de rostros de cráneos precolombinos. Su interés científico era amplio y pasaba más allá de su campo de especialización, investigando por ejemplo en crónicas hispanas para contextualizar sus artículos en temas como los perros andinos.

A continuación destacamos algunos de los logros académicos y profesionales de Marvin Allison:

Pregrado en pre-Medicine y lingüística del College of William and Mary, 1942

Master en fisiología, University of Pennsylvania, 1947

Doctorado en Experimental Pathology, 1960

Profesor emérito del Colegio Médico de Virginia, nombrado en 1985

Becado Fulbright

Numerosos grants de la NASA, National Geographic, Earthwatch y FONDECYT.

Finalizamos nuestras palabras destacando que Marvin era una persona muy alegre, excelente amigo, mentor y colega. Era un latino más, disfrutaba de la música andina y de las comidas típicas, y además sobresalía por sus casi dos metros de estatura. Era también muy generoso con su tiempo: fue nuestro maestro de inglés en clases informales pero entretenidas en el campus Azapa. Fue además un buen deportista. Le encantaba jugar tenis en las canchas de la Universidad de Tarapacá, donde algunos de nosotros fuimos su compañero en campeonatos de dobles o sus oponentes en partidos de singles. Jugaba con una enorme raqueta con la cual se at Universidad de Tarapacá. After this initial action and many subsequent collective efforts, this undergraduate archaeology program finally materialized in 2006, thanks to a MECESUP contribution.

His legacy also continues in the Museo Arqueológico de Azapa where the physical anthropology laboratory that he began is currently located. It must be emphasized that he contributed significantly to the creation of the teams of researchers that have continued in these areas. In that sense, he was a mentor whose presence is still felt in the Departamento de Antropología, through researchers like Bernardo Arriaza and Vivien Standen, who felt motivated to obtain their doctorate degrees in bioanthropology. Moreover, he was a recognized lecturer. He also brought specialists to Chile, who were the first to perform facial reconstructions of pre-Columbian skulls. His scientific interests were broad and went beyond his field of specialization, researching for background information in Spanish chronicles to contextualize his articles in subjects like Andean dogs.

Next we highlight some of Marvin Allison's academic and professional achievements:

Pre-Med and Linguistics, College of William and Mary, 1942

Masters in Physiology, University of Pennsylvania, 1947

Doctorate degree in Experimental Pathology, 1960

Professor Emeritus from the Medical College of Virginia, named in 1985

Fulbright scholarship recipient

Numerous grants from NASA, National

Geographic, Earthwatch and FONDECYT.

We finalize our words emphasizing that Marvin was a very lively person, an excellent friend, mentor, and colleague. He was a Latino, he enjoyed Andean music and traditional food and he stood out due to his almost 2-meter height. He was also very generous with his time: he was our English teacher in informal but fun classes on the Azapa campus. He was also a good athlete. He enjoyed playing tennis at the Universidad de Tarapacá courts, where some of us were his partners in doubles tournaments or his opponents in a singles match. He played with a large tennis racket, that he used 
divertía haciendo pelotas cortas para el fastidio de sus rivales. También en Arica conoció a Nancy Hume, quien en ese entonces trabajaba en el Museo Arqueológico San Miguel de Azapa, de esta unión nació su hija Rachel. Ciertamente extrañaremos a Marvin y le rendimos un sincero homenaje a nuestro amigo y maestro de muchas generaciones. Él supo plantar la inquietud de la investigación en nosotros y contribuyó significativamente a nuestro desarrollo profesional. to amuse himself by serving short balls to annoy his rivals. He also met Nancy Hume in Arica, who at the time worked at the Museo Arqueológico San Miguel de Azapa. His daughter Rachel was born from this union. We will admittedly miss Marvin and pay sincere tribute to our friend and teacher from many generations. He succeeded in planting the seeds of the curiosity of research within us and contributed significantly to our professional development.

\section{Publicaciones Antropológicas Seleccionadas}

Allison, M., B. Arriaza, G. Focacci e I. Muñoz 1983. Los Orejones. Chungara 11:167-172.

Allison, M., G. Focacci, B. Arriaza, V. Standen, M. Rivera y J. Lowenstein 1984. Momias Chinchorro de preparación complicada: métodos de momificación. Chungara 13:155-174.

Allison, M.J., G. Focacci, E. Gerszten, M. Fouant y M. Cebelin 1982. La sífilis ¿una enfermedad americana? Chungara 9:275-283.

Allison, M.J., E. Gerszten, J. Munizaga y C. Santoro 1980. Metastatic tumor of bone in a Tiahuanaco female. Bulletin of the New York Academy of Medicine 56:581-587.

Allison, M.J., E. Gerszten, J. Munizaga, C. Santoro y G. Focacci 1981. La práctica de la deformación craneana entre los pueblos andinos precolombinos. Chungara 7:238-260.

Allison, M.J., L. Lindberg, C. Santoro y G. Focacci 1981. Tatuajes y pintura corporal de los indígenas precolombinos de Perú y Chile. Chungara 7:218-236.

Allison, M.J., D. Mendoza y A. Pezzia 1973. Documentation of a case of tuberculosis in Pre-Columbian America. The American Review of Respiratory Disease 107:985-991.

Allison, M.J., A. Pezzia, I. Hasegawa y E. Gerszten 1974. A case of hookworm infestation in a Precolumbian American. American Journal of Physical Anthropology 41:103-106.

Arriaza, B., M. Allison y E. Gerszten 1988. Maternal mortality in Pre-Columbian Indians of Arica. American Journal of Physical Anthropology 77:35-41.
Arriaza, B., M. Allison y V. Standen 1984. Líneas de Harris en una población arcaica tardía del extremo norte de Chile. Chungara 13:187-191.

Arriaza, B., M. Allison, V. Standen, G. Focacci y J. Chacama 1986. Peinados precolombinos de Arica. Chungara 16-17:353-375.

Aufderheide, A.C. y M.J. Allison 1995. Chemical dietary reconstruction of north Chile prehistoric populations by trace mineral analysis. Proceedings of the First World Congress on Mummy Studies Volumen 1, pp. 451-461. Museo Arqueológico y Etnográfico de Tenerife, Organismo Autónomo de Museos y Centros, Cabildo de Tenerife.

Fontana, D., M. Allison, E. Gerszten y B. Arriaza 1983. Enfermedades respiratorias Agudas en los habitantes precolombinos del norte grande chileno. Chungara 11:153-160.

Munizaga, J., M.J. Allison, E. Gerszten y D.M. Klurfeld 1975. Pneumoconiosis in Chilean miners of the 16th century. Bulletin of the New York Academy of Medicine 51:1281-1293.

Rothhammer, F., M. Allison, V. Standen, L. Nuñez y B. Arriaza 1986. Chagas's disease in Pre-Columbian South America. American Journal of Physical Anthropology 68:495-498.

Standen, V., M. Allison y B. Arriaza 1984. Patologías óseas de la población Morro-1 asociada al Complejo Chinchorro: Norte de Chile. Chungara 13:175-185.

Standen, V., M. Allison y B. Arriaza 1985. Osteoma del conducto auditivo externo: Hipótesis en torno a una posible patología laboral prehispánica. Chungara 15:197-209. 
